\title{
Editorial
}

\section{Should Infant Formula Provide Both Omega-3 DHA and Omega-6 Arachidonic Acid?}

\author{
Berthold Koletzko ${ }^{\text {a }}$ Susan E. Carlson ${ }^{\text {b }}$ Johannes B. van Goudoever ${ }^{c}$ \\ a Ludwig-Maximilians-University of Munich, Dr. von Hauner Children's Hospital, University of Munich Medical

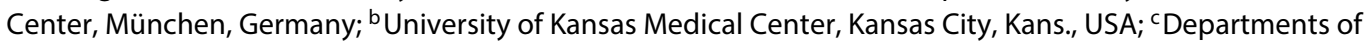 \\ Paediatrics, Emma Children's Hospital, Academic Medical Center, and VU University Medical Center, Amsterdam, \\ The Netherlands
}

The long-chain polyunsaturated fatty acids (LCPUFA), docosahexaenonic acid (22:6n-3, DHA) and arachidonic acid (20:4n-6, ARA) are deposited in relatively large amounts in human tissues, including the brain, during pregnancy and infancy $[1,2]$. Fetal accretion of both DHA and ARA during pregnancy is facilitated by their preferential materno-fetal transfer across the placenta [3]. After birth, human milk provides both DHA and ARA to breastfed infants [4]. A survey of 65 studies on the composition of human milk from 2,474 women worldwide indicated a mean DHA content of $0.32 \%$ (wt/wt; range $0.06-1.4 \%$ ), while the mean content of ARA was higher with $0.47 \%(0.24-1.0 \%)$ [5]. For more than two decades, DHA along with ARA has been added to infant formulae in an attempt to partly mimic the nutrient supply and functional effects achieved with breast feeding $[6,7]$. Current compositional requirements for infant formula in the European Union [8] and globally [9] stipulate the optional addition of DHA to infant formula, provided that the ARA content is equal to or higher than the DHA content $[4,5]$, thus following the model of typical human milk composition.

Recently, the European Food Safety Authority (EFSA) determined adequate nutrient intakes of LC-PUFA for the majority of infants from birth to the age of 6 months as $100 \mathrm{mg}$ DHA/day and $140 \mathrm{mg}$ ARA/day [10]. These conclusions were supported by recent recommendations of a global expert group, based on a systematic review of the available scientific evidence [11]. In contrast, an EFSA opinion on the compositional requirements of infant and follow-on formula advised that all infant and follow-on formula should contain relatively high amounts of 20-50 mg DHA/100 kcal, but without the need to provide any ARA [12]. At an assumed mean formula fat content of $5.2 \mathrm{~g} 100 \mathrm{kcal}$, this recommendation would lead to a DHA content of $0.38-0.96 \%$ of fatty acids, higher than about $0.2-0.3 \%$ DHA found in most DHA enriched formulae for term infants marketed in Europe today, which however all contain also preformed ARA at levels equal to or higher than the DHA content.

While infant formula providing both DHA and ARA have been evaluated in numerous controlled trials in infants, the use of term infant formula with up to $1 \%$ DHA and no ARA is a novel approach that has not been systematically tested for its effects, suitability and safety. ARA is an essential component of all cell membranes. The amount of ARA incorporated into the developing brain during infancy exceeds the deposition of DHA $[1,2]$. Although humans can synthesize ARA to some extent from linoleic acid, infants-fed formula without pre-formed

\section{KARGER 125}

(c) 2015 S. Karger AG, Base

0250-6807/15/0663-0137\$39.50/0
Prof. Berthold Koletzko

Ludwig-Maximilians-University of Munich, Dr. von Hauner Children's Hospital University of Munich Medical Center, Lindwurmstrasse 4 DE-80337 München (Germany)

E-Mail office.koletzko@med.lmu.de 
ARA tend to develop lower ARA levels in blood plasma and erythrocytes than breast-fed infants who receive both DHA and ARA $[13,14]$.

The provision of high amounts of n-3 LC-PUFA without a concomitant supply of ARA has been associated with adverse effects on growth in premature infants [15, 16]. Further concerns regarding the effects of a high supply of DHA without increasing ARA intakes to infants are raised by the findings of a randomised controlled trial assigning term infants to formula providing either no LCPUFA, or different levels of DHA intakes of $0.32,0.64$ and $0.96 \%$ at the same ARA level of $0.64 \%$, with developmental testing of the participating children up to the age 6 [17]. While positive effects in tests on word production, a card sorting task and an intelligence test were observed with the two lower DHA doses, performance of children assigned to the highest DHA dose of $0.96 \%$ but with a reduced ratio of dietary ARA to DHA was attenuated [17]. Nonhuman primates were fed these same DHA and ARA intakes, and various regions of their brains were analysed. The formula with $0.96 \%$ DHA significantly reduced ARA in all regions of the brain analysed despite the fact that the higher DHA intake was accompanied by $0.64 \%$ ARA [18]. These human and nonhuman primate results question the suitability and safety of the approach recommended by EFSA, that is, to provide infant formula from birth with up to $1 \%$ of fatty acids as DHA without a proportional increase in the intake of ARA.

It is widely agreed that any major change in infant formula composition should be subjected to a full pre-clinical and clinical evaluation of nutritional adequacy and safety prior to its introduction into the market $[19,20]$. We consider it premature to accept the use of formula for infants from birth with the addition of $20-50 \mathrm{mg} / 100$ kcal DHA to infant formula without added ARA in the absence of confirmed data on the suitability and safety from a thorough clinical evaluation of this novel approach.

\section{References}

1 Martinez M: Tissue levels of polyunsaturated fatty acids during early human development. J Pediatr 1992;120:S129-S138.

2 Makrides M, Neumann MA, Byard RW, Simmer K, Gibson RA: Fatty acid composition of brain, retina, and erythrocytes in breast- and formula-fed infants. Am J Clin Nutr 1994;60: 189-194.

3 Larque E, Ruiz-Palacios M, Koletzko B: Placental regulation of fetal nutrient supply. Curr Opin Clin Nutr Metab Care 2013;16: 292-297.

4 Koletzko B, Agostoni C, Bergmann R, Ritzenthaler K, Shamir R: Physiological aspects of human milk lipids and implications for infant feeding: a workshop report. Acta Paediatr 2011;100:1405-1415.

5 Brenna JT, Varamini B, Jensen RG, DiersenSchade DA, Boettcher JA, Arterburn LM: Docosahexaenoic and arachidonic acid concentrations in human breast milk worldwide. Am J Clin Nutr 2007;85:1457-1464.

6 Makrides M, Neumann MA, Simmer K, Gibson RA: Erythrocyte fatty acids of term infants fed either breast milk, standard formula, or formula supplemented with longchain polyunsaturates. Lipids 1995;30: 941-948.

7 Koletzko B, Schmidt E, Bremer HJ, Haug M, Harzer G: Effects of dietary long-chain polyunsaturated fatty acids on the essential fatty acid status of premature infants. Eur J Pediatr 1989;148:669-675.
8 European-Commission: Commission Directive 2006/141/EC of 22 December 2006 on infant formulae and follow-on formulae and amending Directive 1999/21/EC. Official Journal of the European Union, 2006 (L 401/1).

9 Codex Alimentarius Commission: Standard for Infant Formula and Formulas for Special Medical Purposes Intended for Infants. Codex STAN 72-1981. Rome, Codex Alimentarius Commission, 2007, pp 1-21.

10 European Food Safety Authority (EFSA): Scientific opinion on nutrient requirements and dietary intakes of infants and young children in the European Union. EFSA Journal 2013; 11:3408.

11 Koletzko B, Boey CC, Campoy C, Carlson SE, Chang N, Guillermo-Tuazon MA, et al: Current information and Asian perspectives on long-chain polyunsaturated fatty acids in pregnancy, lactation, and infancy: systematic review and practice recommendations from an early nutrition academy workshop. Ann Nutr Metab 2014;65:49-80.

12 European Food Safety Authority (EFSA): Scientific opinion on the essential composition of infant and follow-on formulae. EFSA Journal 2014; $12: 3760$.

13 Koletzko B, Sauerwald T, Demmelmair H, Herzog M, von Schenck U, Bohles $\mathrm{H}$, et al: Dietary long-chain polyunsaturated fatty acid supplementation in infants with phenylketonuria: a randomized controlled trial. J Inherit Metab Dis 2007;30:326-332.
14 Carlson SE: Docosahexaenoic acid and arachidonic acid in infant development. Semin Neonatol 2001;6:437-449.

15 Carlson SE, Werkman SH, Peeples JM, Cooke RJ, Tolley EA: Arachidonic acid status correlates with first year growth in preterm infants. Proc Natl Acad Sci U S A 1993;90:1073-1077.

16 Scholtz SA, Colombo J, Carlson SE: Clinical overview of effects of dietary long-chain polyunsaturated fatty acids during the perinatal period. Nestle Nutr Inst Workshop Ser 2013; 77:145-154.

17 Colombo J, Carlson SE, Cheatham CL, Shaddy DJ, Kerling EH, Thodosoff JM, et al: Longterm effects of LCPUFA supplementation on childhood cognitive outcomes. Am J Clin Nutr 2013;98:403-412.

18 Hsieh AT, Anthony JC, Diersen-Schade DA, Rumsey SC, Lawrence P, Li C, et al: The influence of moderate and high dietary long chain polyunsaturated fatty acids (LCPUFA) on baboon neonate tissue fatty acids. Pediatr Res 2007;61:537-545.

19 Koletzko B, Ashwell M, Beck B, Bronner A, Mathioudakis B: Characterisation of infant food modifications in the European Union. Ann Nutr Metab 2002;46:231-242.

20 Aggett PJ, Agostini C, Goulet O, Hernell O, Koletzko B, Lafeber HL, et al: The nutritional and safety assessment of breast milk substitutes and other dietary products for infants: a commentary by the ESPGHAN committee on nutrition. J Pediatr Gastroenterol Nutr 2001;32:256-258. 